\title{
Acinetobacter-associated nosocomial infections in Cumhuriyet University Medical Faculty Research Hospital: Three years' experience
}

\section{Cumhuriyet Üniversitesi Tıp Fakültesi Hastanesinde nozokomiyal acinetobacter enfeksiyonları ve antibiyotik duyarlılıklarının değerlendirilmesi: Üç yıllık izlem}

\author{
Aynur Engin
}

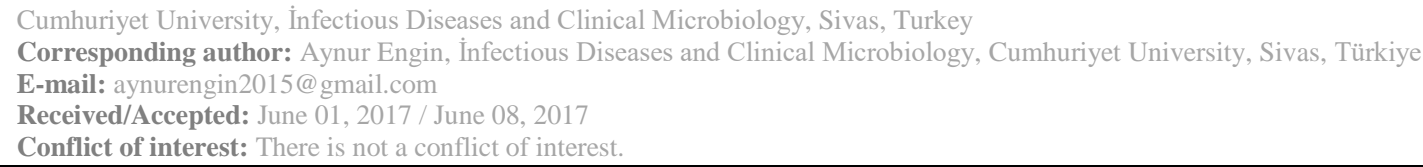

\section{SUMMARY}

Objective: Nosocomial infections have high mortality and morbidity. Acinetobacter is a Gram-negative bacilli and an important nosocomial pathogen. The number of nosocomial infections caused by antibiotic resistant-Acinetobacter strains has increased in recent years. Monitoring these bacterial infections which are difficult to treat, and antibiotic susceptibility, is very important for the appropriate treatment of patients. In this study, nosocomial infections caused by Acinetobacter in the hospital of Cumhuriyet University Medical Faculty during 2014-2016 were investigated.

Method: Acinetobacter-associated nosocomial infections and their rate of antibiotic resistance in patients hospitalizing in the Cumhuriyet University Medical Faculty Research Hospital between January 2014 and December 2016 were retrospectively investigated. The data of this study are the surveillance data of the infection control committee and were obtained from the 3 years data registered in the infline software.

Results: The rate of infection was $3.81 \%$ in the hospital, however, it was $30.86 \%$ in the Anesthesiology intensive care unit (ICU). In 2016, the rate of infection was lower in the hospital, whereas, it was higher in the Anesthesiology ICU. The number of Acinetobacter strains as a causative agent in the nosocomial infections were higher in 2016, too.

In $7.16 \%$ of the nosocomial infections, Acinetobacter species were detected as the causative agent; Acinetobacter baumannii constituting $94.5 \%$.

Only two cases of colistin resistance were seen. Tigecycline resistance was detected in one strain. Meropenem and imipenem resistance were $91.1 \%$ and $93.8 \%$ for A. baumannii, respectively. Ventilator-associated pneumonia was the most common nosocomial infection due to Acinetobacter baumannii.

Conclusions: Acinetobacter strains are among the most important nosocomial pathogens in our hospital. At the same time, the antibiotic resistance is increasing among Acinetobacter strains. Regular monitoring of these bacterial infections and in vitro susceptibility profiles of them is necessary to ensure an appropriate empirical treatment of Acinetobactermediated nosocomial infections.

Keywords: Acinetobacter, nosocomial infection, antibiotic resistance, Cumhuriyet University

\section{ÖZET}

Amaç: Nozokomiyal enfeksiyonlar mortalite ve morbiditenin yüksek olduğu enfeksiyonlardır. Acinetobacter, Gram negatif bir basil olup önemli bir nozokomiyal enfeksiyon etkenidir. Son y1llarda özellikle çeşitli antibiyotiklere dirençli Acinetobacter suşlarında artı̧̧ gözlenmektedir. Tedavisi zor olan bu bakteriye bağlı enfeksiyonların ve antibiyotik duyarlılıklarının izlenmesi hastaların uygun tedavisi açısından çok önemlidir.Bu çalışmada 2014-2016 yılları boyunca Cumhuriyet Üniversitesi Tip Fakültesi hastanesinde gelişen Acinetobacter kaynaklı nozokomiyal enfeksiyonlar araştırıldi.

Yöntem: Bu çalışmada, Cumhuriyet Üniversitesi Tıp Fakültesi hastanesine yatan hastalarda gelişen Acinetobacter kaynaklı nozokomiyal enfeksiyonlar ve bakterinin antibiyotik direnç durumu 3 yıllık dönem boyunca İnfeksiyon Kontrol Komitesinin surveyans kayıtlarından retrospektif olarak alındı. 
Bulgular: Hastane genelinde \%3.81 olan enfeksiyon hızı, Anestezi ve Reanimasyon yoğun bakım ünitesinde (YBÜ) \%30.86'idi. Enfeksiyon hızı 2016 yılında diğer yıllara kıyasla daha azdı, oysa Anestezi ve Reanimasyon YBÜ’deki enfeksiyon hızı ve etken olan Acinetobacter sayısı diğer y1llara kiyasla daha fazlaydı. Nozokomiyal enfeksiyon etkenlerinin \%7.16'sını Acinetobacter türü bakteriler oluşturdu. Etken olan Acinetobacterlerin \%94.5'u ise Acinetobacter baumannii idi.

Kolistin direnci sadece 2 hastada görüldü. Tigesiklin direnci sadece bir bakteride saptandı. Nozokomiyal enfeksiyona yol açan Acinetobacter baumannii suşlarının \%91.1'inde meropeneme, \%93.8'inde imipeneme direnç saptandı. Hastanemizde Acinetobacter baumannii'ye bağlı olarak gelişen nozokomiyal enfeksiyonlardan en fazla görüleni "ventilatör ilişkili pnömoni”ydi.

Sonuç: Acinetobacter türü bakterilerin hastanemizde giderek artan önemli bir nozokomiyal etken olduğu ve antibiyotik direncinin fazla olduğu görüldü. Acinetobacter kaynaklı nozokomiyal enfeksiyonların ampirik tedavilerinin doğru şekilde yapılması açısından bu bakteriye bağlı enfeksiyonların ve in vitro duyarlılık profillerinin düzenli biçimde izlenmesi gereklidir.

Anahtar sözcükler: Acinetobacter, nozokomiyal enfeksiyon, antibiyotik direnci, Cumhuriyet Üniversitesi

\section{INTRODUCTION}

Nosocomial infections, i.e. hospital-acquired infections might lead to an increase of hospitalization duration and treatment expenses, as well as an increase in mortality and morbidity. Especially in the recent years, bacteria of the Acinetobacter species, a gram-negative bacillus are encountered as a substantial factor in nosocomial infections. These bacteria, which also may be causative in community-acquired infections, may cause severe infections, including pneumonia, wound site infections, urinary system infections, bacteremia and meningitis in hospitalized severe patients ${ }^{1}$.

In a study conducted in the Anesthesiology Intensive Care Unit between 2004 and 2008, Akın et al. identified that a nosocomial infection rate of $17.9 \%$ and reported that Acinetobacter baumannii was the cause in a significant proportion of these infections ${ }^{2}$. Avc1 et al. reported that Acinetobacter baumannii determined $9.6 \%$ of instrumentassociated infections that occurred in the Anesthesiology Intensive Care Unit ${ }^{3}$. The reported infections included ventilator-associated pneumonia, central venous catheter-associated bloodstream infection and catheter-associated urinary system infections. Acinetobacter-type bacteria are able to resist to many antibiotics. Thus, their infections are difficult to treat and their mortality may increase. Acinetobacters can also resist to carbapenem, a broad-spectrum antibiotic. The rate of resistance to this antibiotic is increasing. Hence, in the study by Alpat et al., the reported rate of resistance of Acinetobacter strains to imipenem and meropenem were as high as $43.2 \%$ and $64.4 \%$, respectively ${ }^{4}$. Also, Balc1 et al. investigated the resistance rate of Acinetobacter strains to antibiotics and found high resistance values ${ }^{5}$. In their study, resistance rates were found as $84 \%$ to piperacillin/tazobactam, $82 \%$ to ciprofloxacin, $81 \%$ to ampicillin/sulbactam, $63 \%$ to meropenem and $49 \%$ to imipenem. A such high resistance to antibiotics may complicate the choice of the right antibiotic in empiric treatment, increasing the patients' mortality. In fact, in the study by Gorbich et al. investigating patients with A. baumannii-associated nosocomial infections, it was confirmed that mortality decreased in patients that properly received antibiotic treatment ${ }^{6}$.

It is essential to know which possible agents may cause nosocomial infections, especially in units hospitalizing severe patients, including intensive care units (ICU), and their antimicrobial sensitivity patterns. These data are valuable in immediately starting the right treatment in patients with severe prognosis. Bacterial culture of patients results in approximately 3 days, yet, treatment for septic patients has to begin in hours, even minutes. In every hospital, even department, there are different infection agents and different resistance patterns. Therefore, the Infection Control Committees of hospitals regularly watch the occurring hospital infections, their causative factors and their status of antibiotic susceptibility, records their registries and reports them to the clinics and organs of the Ministry of Health.

In this study, it was aimed to assess the Acinetobacter-associated nosocomial infections that developed in patients hospitalized between 2014 and 2016, proportional incidence of Acinetobacter-type bacteria in all nosocomial infections, nosocomial infection rate, distribution of these infections according to systems and their susceptibility to antibiotics. Thus, significant data on Acinetobacter-associated nosocomial infections and their status of resistance to antibiotics will be obtained and a contribution to determining the empiric treatments of patients in terms of surveillance data will be available.

\section{MATERIAL AND METHODS}

In this study, Acinetobacter-associated nosocomial infections and their rate of antibiotic resistance in patients hospitalizing in the Cumhuriyet University 
Medical Faculty Research Hospital between January 2014 and December 2016 were retrospectively investigated. This study was approved by the ethical committee.

In our hospital, active prospective surveillance based on patients and laboratory is performed by the infection control unit in order to detect and prevent nosocomial infections. The obtained data were reported to the "National Nosocomial Infections Surveillance Network" (UHESA) via the infline databank. The data of this study are the surveillance data of the infection control committee and were obtained from the 3 years data registered in the infline software. Nosocomial infection diagnosis was made according to the criteria of the Centers for Disease Control and Prevention (CDC) published in $20088^{7}$. Nosocomial infection rate was calculated with the following formula: The number of nosocomial infections during a defined time frame/Number of all hospitalized patients at the same time interval X100. Infections/causative agents counts and status of antibiotic resistance were expressed as numbers or percentage.

\section{RESULTS}

During our study period, between 01.01.2014 and 31.12.2016, 53369 patients hospitalized. Of these patients, 2033 developed a nosocomial infection. The infection rate of our hospital during the mentioned period was $3.81 \%$ (Table 1). Of the detected nosocomial infections, 467 were in the anesthesiology ICU, 197 in the general surgery department, 144 in the nephrology department, 136 in the haematology department and 133 in the neonatal ICU.

Table 1. The patients hospitalized in the anesthesiology ICU and in our hospital, number of nosocomial infections and infection rates by years.

\begin{tabular}{|l|l|l|l|}
\hline \multicolumn{5}{|l|}{ TOTAL } \\
\hline Year & Number of patients (n) & Number of infections (n) & Rate of infection \\
\hline 2014 & 16270 & 713 & 4.38 \\
\hline 2015 & 18726 & 682 & 3.64 \\
\hline 2016 & 18373 & 638 & 3.47 \\
\hline Toplam & 53369 & 2033 & 3.81 \\
\hline ANESTHESIOLOGY INTENSIVE CARE UNIT \\
\hline 2014 & 498 & 154 & 30.92 \\
\hline 2015 & 528 & 150 & 28.41 \\
\hline 2016 & 487 & 163 & 33.47 \\
\hline Total & 1513 & 467 & 30.86 \\
\hline
\end{tabular}

When inspected by years, it was found that the lowest infection rate level in the hospital was in 2016. Although the infection rate of that year was lower, the infection rate in the Anesthesiology and reanimation ICU in 2016 was remarkably high (henceforth, Anesthesiology and Reanimation ICU will be expressed as "Anesthesiology ICU" in this manuscript). During the 3 years period, a total of 2024 pathogens were detected in nosocomial infections in the hospital. The common causative agents of nosocomial infections in our hospital from 2014 to 2016 was shown Table 2. 145 (7.16\%) of these were Acinetobacters. Among the Acinetobacter types, Acinetobacter baumannii was the most common with 94.5\% (137/145). The number of Acinetobacter types detected as a nosocomial infection pathogen by year is presented in Table 3.

Table 2. The common causative agents of nosocomial infections in Cumhuriyet University Medical Faculty Research Hospital from 2014 to 2016.

\begin{tabular}{|l|l|}
\hline Causative agent & $\mathrm{n}$ \\
\hline Escherichia coli & 425 \\
\hline Klebsiella K. pneumoniae, K. oxytoca, K. rhinoscleromatis and K. spp.) & 259 \\
\hline Enterococcus (E. faecalis, E. faecium and E. spp.) & 251 \\
\hline Staphylococcus aureus & 204 \\
\hline Coagulase-negative staphylococci & 185 \\
\hline Pseudomonas $($ P. aeruginosa and $P$. spp.) & 157 \\
\hline Acinetobacter (A. baumannii, A. lwoffii and A. spp.) & 145 \\
\hline Candida albicans & 88 \\
\hline Non-albicans Candida species & 59 \\
\hline
\end{tabular}


Table 3. The distribution of Acinetobacter types detected as a nosocomial infection pathogen by years.

\begin{tabular}{|l|l|l|l|l|}
\hline Year & Acinetobacter baumannii $(\mathrm{n})$ & Acinetobacter lwoffii $(\mathrm{n})$ & Acinetobacter $\mathrm{spp} .(\mathrm{n})$ & Total $(\mathrm{n})$ \\
\hline 2014 & 50 & 1 & 1 & 52 \\
\hline 2015 & 31 & 1 & 5 & 37 \\
\hline 2016 & 56 & 0 & 0 & 56 \\
\hline $\mathbf{2 0 1 4 - 2 0 1 6}$ & 137 & 2 & 6 & 145 \\
\hline
\end{tabular}

During the study period, Acinetobacter-associated nosocomial infections were the most common in 2016.

According to the resistance to antibiotics, colistin resistance was detected in 2 strains in the 3-years period. Both of these infections were central venous catheter-associated bloodstream infections that developed in the anesthesiology ICU. While one of their pathogens was Acinetobacter baumannii, the other pathogen was Acinetobacter spp. In 2014 and 2015, no strain was studied on tigecycline, while in 2016, only 2 strains were studied and resistance was detected in one. It was shown that the number of antibiotic resistant Acinetobacter strains causing nosocomial infections by years in Table 4 .

Table 4. The number of antibiotics resistant Acinetobacter strains causing nosocomial infections by years.

\begin{tabular}{|c|c|c|c|c|c|c|c|}
\hline Antibiotic & \multicolumn{3}{|c|}{ Acinetobacter baumannii (n) } & \multicolumn{2}{|c|}{ Acinetobacter lwoffii (n) } & \multicolumn{2}{|c|}{ Acinetobacter spp. (n) } \\
\hline & 2014 & 2015 & $2016^{*}$ & 2014 & 2015 & 2014 & 2015 \\
\hline Amikacin & 40 & 29 & 50 & 0 & 0 & 1 & 3 \\
\hline İmipenem & 40 & 28 & 54 & 0 & 0 & 1 & 3 \\
\hline Colistin & 1 & 0 & 0 & - & 0 & 0 & 1 \\
\hline Meropenem & 38 & 22 & 43 & 0 & 0 & 1 & 2 \\
\hline Ciprofloxacin & 44 & 28 & 50 & - & - & 1 & 3 \\
\hline Cefepime & 45 & 13 & - & 0 & 0 & 1 & 2 \\
\hline Piperacillin-tazobactam & 47 & 15 & 2 & 1 & 0 & 1 & 2 \\
\hline Ampicillin-sulbactam & 46 & 15 & - & 0 & 0 & 1 & 2 \\
\hline Tigecycline & - & - & 1 & - & - & - & - \\
\hline
\end{tabular}

Antibiotic resistance was most seen in ICUs. During the 3-years period, nosocomial infection causing Acinetobacter types were analyzed in Anesthesiology ICU, the largest ICU of our hospital. Acinetobacter baumannii and Acinetobacter spp.-associated infections were present in this unit, but no Acinetobacter lwoffiiassociated infection was detected.

In our study, Acinetobacter-associated nosocomial infections were analyzed for 2014, 2015 and 2016, separately.
In 2014,16270 patients were admitted to our hospital and 713 of them developed a nosocomial infection (Table 1). A total of 728 nosocomial infections were detected in our hospital in 2014. Of these infections, 50 were caused by Acinetobacter baumannii, 1 by Acinetobater lwoffii, and 1 by Acinetobacter spp., thus, total 52 of them were caused by Acinetobacter. Table 5 demonstrates the distribution of Acinetobacter-associated nosocomial infections according to infection site. 
Table 5. The distribution of Acinetobacter-associated nosocomial infections according to infection site by years.

\begin{tabular}{|c|c|c|c|c|c|c|c|c|c|}
\hline \multirow[t]{2}{*}{ Infection site } & \multicolumn{3}{|c|}{$\begin{array}{l}\text { Acinetobacter } \\
\text { baumannii (n) }\end{array}$} & \multicolumn{3}{|c|}{$\begin{array}{l}\text { Acinetobacter lwoffii } \\
\text { (n) }\end{array}$} & \multicolumn{3}{|c|}{$\begin{array}{l}\text { Acinetobacter spp. } \\
\text { (n) }\end{array}$} \\
\hline & 2014 & 2015 & 2016 & 2014 & 2015 & 2016 & 2014 & 2015 & 2016 \\
\hline $\begin{array}{l}\text { Ventilator-associated } \\
\text { pneumonia }\end{array}$ & 17 & 13 & 27 & - & - & - & - & - & - \\
\hline $\begin{array}{l}\text { Central venous catheter- } \\
\text { bloodstream infection }\end{array}$ & 13 & 9 & 10 & - & - & - & - & 1 & - \\
\hline $\begin{array}{l}\text { Laboratory-confirmed } \\
\text { bloodstream infection }\end{array}$ & 5 & 1 & 3 & 1 & - & - & - & - & - \\
\hline $\begin{array}{l}\text { Catheter-associated urinary } \\
\text { tract infections }\end{array}$ & 2 & 5 & 3 & - & - & - & - & - & - \\
\hline $\begin{array}{l}\text { Pneumonia with specific } \\
\text { laboratory findings }\end{array}$ & 5 & - & 2 & - & - & - & 1 & - & - \\
\hline Clinically defined pneumonia & - & - & 1 & - & - & - & - & - & - \\
\hline $\begin{array}{l}\text { Lower respiratory tract } \\
\text { infection, other } \\
\text { than pneumonia }\end{array}$ & - & - & 1 & - & - & - & - & - & - \\
\hline Conjunctivitis & 2 & 1 & - & - & - & - & - & - & - \\
\hline $\begin{array}{l}\text { Deep incisional primary } \\
\text { surgical site infection }\end{array}$ & 4 & - & 5 & - & - & - & - & 2 & - \\
\hline $\begin{array}{l}\text { Superficial incisional primary } \\
\text { surgical site infection }\end{array}$ & - & - & 1 & - & 1 & - & - & 5 & - \\
\hline Post-neurosurgical meningitis & 1 & - & - & - & - & - & - & - & - \\
\hline $\begin{array}{l}\text { Postoperative intracranial } \\
\text { infection }\end{array}$ & - & 1 & - & - & - & - & - & - & - \\
\hline Soft tissue infection & 1 & - & 1 & - & - & - & - & - & - \\
\hline $\begin{array}{l}\text { Postoperative intraabdominal } \\
\text { infection }\end{array}$ & - & 1 & 2 & - & - & - & - & 2 & - \\
\hline
\end{tabular}

In 17 patients, Acinetobacter baumannii caused ventilator-associated pneumonia in 2014. Fifteen (15) of them were studied for colistin resistance; all were found susceptible to colistin.

The antibiotic resistant Acinetobacter strains that were causative for nosocomial infections in the hospital by years are presented in Table 4 .

In 2014, only one Acinetobacter baumannii strain was identified as resistant to colistine. This bacterium was the agent in a central venous catheter-associated bloodstream infection in the Anesthesiology ICU.

We also analyzed Acinetobacter-associated nosocomial infections for 2015 .

In 2015 , it was found that 18726 patients were admitted to our hospital and 682 of them experienced a nosocomial infection. Of the admitted patients, 528 were hospitalized in the Anesthesiology ICU and 150 of them developed an infection (Table 1).

In 2015, a total of 622 nosocomial infection causative agents were detected in our hospital; 37 of these causative agents were Acinetobacters, including Acinetobacter baumannii $(\mathrm{n}=31)$, Acinetobacter lwoffi $(\mathrm{n}=1)$ and Acinetobacter $\mathrm{spp}$. . The distributions of Acinetobacter-associated infections are listed in Table 5.

In 2015, only one Acinetobacter infection was identified as resistant to colistin. This infection was an Acinetobacter spp.-associated central venous catheter-bloodstream infection.

We also investigated the Acinetobacter-associated nosocomial infections for 2016 in our study.

In 2016, 18373 patients hospitalized, 638 of them developed a nosocomial infection (Table 1). In that year, a total of 674 nosocomial infection agents were identifies; 56 of them were Acinetobacter baumannii. No Acinetobacter lwoffi and Acinetobacter spp-associated infection was observed. The distribution of Acinetobacterassociated infections according to type of infections is listed in Table 5.

No Acinetobacter strain that determined a nosocomial infection in our hospital in 2016 was found resistant to colistin (Table 4). 


\section{DISCUSSION}

In the 3-year period, between 2014 and 2016, the nosocomial infection rate in our hospital was found as $3.81 \%$. The infection rate in the Anesthesiology ICU was $30.86 \%$. When analyzed by year, 2016 was the year with the lowest infection rate in our hospital. In contrast, it was observed that in that year, the Anesthesiology ICU had the highest infection rate and that the number of causative Acinetobacters was higher compared to other years. $94.5 \%$ of the infection-causing Acinetobacters were Acinetobacter baumannii.

During the 3-year period, colistin resistance was only identified in 2 patients who were hospitalized in Anesthesiology ICU and developed "central venous bloodstream infection". While one of the colistin-resistant strains was Acinetobacter baumannii, the other one was Acinetobacter spp.. Tigecycline resistance was only tested in 2 Acinetobacter baumannii strains in 2016 and one of them was found resistant. According to carbapenem resistance, $91.1 \%$ of the Acinetobacter baumannii strains that caused a nosocomial infection and whose susceptibility was reported were resistant to meropenem, and $93.8 \%$ were imipenem-resistant. In 2014, 38 strains were found to be resistant to meropenem, while in 2016 , this number increased to 43 .

During the three-year period, the most common nosocomial infection due to Acinetobacter baumannii in our hospital was "ventilatorassociated pneumonia", followed by "central venous catheter-associated bloodstream infection".

Acinetobacter-type bacteria, especially Acinetobacter baumannii, is a significant cause of nosocomial infections.

Acinetobacters are oxidase negative, aerobic, gram negative coccobacilli that ferment no glucose. These dryness-resistant bacteria can be isolated from reusable medical equipments, including ventilator tubes, monitors for artherial blood pressure and vaporisators. They were also isolated from settings like hands of health care professionals, sinks or pillows ${ }^{8}$. While its virulence is generally low in patients with no immune system disorder, these bacteria may lead to infections with high mortality in immune-deficient patients, patients with malignancy, burn patients and newborn children ${ }^{8}$. Specifically, Acinetobacter type bacteria are a significant nosocomial pathogen in patients that hospitalize in ICUs for a prolonged time and patients mounted a medical device, including a long-term urinary catheter, central venous catheter or mechanical ventilator.
The frequency of this microorganism varies widely by region, but it's the second most common etiologic agent in nosocomial pneumonia among all gram-negative bacterial factors ${ }^{8}$. Apart from pneumonia, it may also induce infections in different systems, including bloodstream infections, wound site infections and urinary system infections, specifically associated with catheters.

In a study by Alici et al. that investigated invasive device-associated nosocomial infections in the ICU, Acinetobacter spp. was reported to be the most common cause for ventilator-associated pneumonia ${ }^{9}$. Karasu et al. analyzed patients in the ICU that developed nosocomial infections and Acinetobacter spp. was found to be responsible for most cases ${ }^{10}$. In their study, Acinetobacter strains composed $24 \%$ of the nosocomial pathogens. They reported that bloodstream infections (48\%) and ventilator-associated pneumonia (33\%) were the most frequent among nosocomial infections and that Acinetobacter spp. was the most detected pathogen in both infections. In the study by Mahamat et al. that investigated A. baumannii strains isolated from clinic samples of hospitalized patients, it was found that respiratory tract infections were more common in the ICU and wound site infections in the other departments. Amongs A. baumannii-associated infections, bloodstream infections were the second most seen in both the ICU and the other departments in their study ${ }^{11}$. Taşova et al. investigated the nosocomial Acinetobacter-associated infections in Çukurova University in 1999, and the most common infection was pneumonia with $40.8 \%{ }^{12} .66 .3 \%$ of the Acinetobacter types isolated by the investigators were A. baumannii, and $33.7 \%$ of them were $A$. lwoffi. In our study, it was seen that a total of 2024 agents were responsible for nosocomial infections during the 3 -year period, and that $7.16 \%(n=145)$ were identified as Acinetobacter strains. Across the infection causes, Escherichia coli was the most frequent among the gram negative bacteria, followed by Klebsiella pneumoniae, Pseudomanas aeruginosa and Acinetobacter species. A. baumannii (94.5\%) was the most seen Acinetobacter species, as also reported in other studies. The most frequent Acinetobacterassociated infection was ventilator-associated pneumonia, followed by central venous catheterassociated bloodstream infection.

The fact that A. baumannii creates a biofilm layer and is able to resist to many antibiotics makes it difficult to control these bacterial infections ${ }^{13}$. Antibiotic resistance is a substantial issue faced in the treatment of these bacteria. Hence, many 
multidrug-resistant Acinetobacter baumanniiassociated nosocomial infections are reported globally ${ }^{8}$. In the recent years, carbapenem is suggested to be the first choice in treatment of Acinetobacter-associated infections due to increasing antibiotic resistance to many drugs. Especially, units like ICUs that follow up severe patients and have a higher antibiotic resistance are more likely to encounter this condition. However, in our country, carbapenemase-producing and carbapenem-resistant Acinetobacter isolates are increasing, as it is globally. This situation is likely to result in difficult in patient treatment and treatment failure, drawing attention of health authorities.

The World Health Organization (WHO) published a list of pathogens that primarily and urgently need new antibiotics in 2017 (http://www. who. int/medicines/publications/WHO-PPL-Short_ Summary_25Feb-ET_NM_WHO.pdf?ua=1). In this list, carbapenem-resistant Acinetobacter baumannii is addressed under the title of primary and critical pathogens with priority. Indeed, the presence of resistance to carbapenem is a serious issue in terms of patient treatment. Unfortunately, the resistance rates of Acinetobacter baumannii strains to many antibiotics, including carbapenem, has been increasing in the recent years.

Cesur et al. investigated the antibiotic susceptibility of multidrug-resistant Acinetobacter baumannii strains isolated from ICUs in the Etlik Training and Research Hospital ${ }^{14}$. The vast majority of these strains (94\%) were found to be resistant to imipenem and meropenem; no resistance to colistin was identified.

In the study Alpat et al., nosocomial infectioncausing Acinetobacter strains were found to be resistant to imipenem (43.2\%) and meropenem $(64.4 \%)^{4}$. The carbapenem resistence of nosocomial infection-inducing Acinetobacter strains in the study by Balc1 et al. was similar. In that study, high resistance rates to piperacillin/tazobactam as $84 \%$, ciprofloxacine as $82 \%$, ampicillin/sulbactam as $81 \%$, meropenem as $63 \%$ and imipenem as $49 \%$ were reported ${ }^{5}$. One study conducted in India that studied nosocomial infections developing in the cardiovascular surgery ICU, the most common pathogen was reported to be Acinetobacter. In this study by Sahu et al., it was found that Acinetobacter strains specifically infect the lower respiratory tract and that the resistance to imipenem was $86 \%$ and $18 \%$ to colistin ${ }^{15}$. In the study by Sohail et al., the analyzed Acinetobacter strains were found to be resistant to imipenem at $90.9 \%$, and meropenem at $90.8 \%$, while only one strain was identified as resistant to cholistin. This bacterium was most commonly isolated form respiratory secretions in the mentioned study ${ }^{16}$.

Recently, carbapenem resistance of Acinetobacters is found to be high, while being lower before. For instance, in the study by Taşova et al., ciprofloxacine resistance of Acinetobacter baumannii strains were reported as $60.4 \%$ and imipenem resistance as $15.5 \%$. Imipenem resistance was slightly higher for $A$. lwoffi and $22.2 \%{ }^{12}$. In another 2007 study by Yurtsever et al. in Izmir, the resistance to imipenem for nosocomial infection-causing A. baumannii strains was found as $35 \%{ }^{17}$.

In our study, $91.1 \%$ of the Acinetobacter baumannii strains that caused nosocomial infections were resistant to meropenem and $93.8 \%$ of them to imipenem. Carbapenem resistance peaked in 2016. In our 3-year study period, only 2 patients were found to be resistant to colistin. These were 2 patients admitted to the Anesthesiology ICU and developed "central venous bloodstream infection". One of the colistinresistant strains was Acinetobacter baumannii, the other one was Acinetobacter spp..

The resistance statuses of Acinetobacter baumannii strains isolated from blood and cerebrospinal fluid samples are collected from some countries, including our country, via a surveillance program of WHO. The activity report of this surveillance network, called CAESAR (Central Asian and Eastern European Surveillance of Antimicrobial Resistance), was published in $2016{ }^{18}$. According to this report that includes data from certain laboratories in Turkey, in 2014 and 2015, Actinobacter strains reproduced from blood and cerebrospinal fluid samples had a carbapenem resistance at $89 \%$, however, no colistin resistance was identified. In a study by Özdem et al. in a training and research hospital in Ankara, it was seen that meropenem resistance increased from $31.8 \%$ in 2007 to $77.3 \%$ in 2009 , and that resistance to imipenem increased from $32.7 \%$ to $64 \%{ }^{19}$.

These data indicate that carbapenem resistance in Acinetobacter strains are increasing. Of course, if the increase in resistance rates can not be controlled, the treatment of patients will be more difficult in the near future. Some centres reported high resistance rates to aminoglycosides and quinolons, apart from carbapenem, in Acinetobacter strains. In a study by Coşar et al. conducted in Konya, status of resistance for Acinetobacter baumannii strains isolated from blood cultures of hospitalized patients was 
analyzed ${ }^{20}$. In the mentioned study, the resistance to amikacin, imipenem, tetracycline and trimethoprim/sulfamethoxazole, ciprofloxacin, cefepime, piperacillin-tazobactam and ceftriaxone were $67 \%, 71 \%, 83 \%, 85 \%, 87 \%, 99 \%$ and $100 \%$, respectively, and no colistin resistance was found. Tigecyclin and colistin resistance are still found low in Acinetobacter strains. In the study by Doruk et al., only two nosocomial infection-causing Acinetobacter strains were found to be resistant to tigecycline, while one was resistant to colistin ${ }^{21}$.

It is important to give proper antibiotic treatment to patients developing a nosocomial infection in terms of the patient's survival. Hence, in the study by Gorbich et al. on patients with A. baumanniiassociated nosocomial infection, it was stated that patients given proper antibiotic treatment had a lower 30 day mortality ${ }^{6}$.

Conclusively, Acinetobacter-type bacteria are a significant nosocomial pathogen. Their treatment is difficult due to their high resistance to variable antibiotics. The antibiotic resistance status of the bacteria may vary upon centres, even departments. The empiric treatment of Acinetobacter-associated nosocomial infections should be given considering the susceptibility of the bacteria. In order to prevent inappropriate antibiotic usage and to determine rational treatment protocols, the in vitro susceptibility profile of this bacteria that is able to cause infections with high mortality and morbidity, should be tracked continuously.

\section{Acknowledgement}

I would like to thank infection control committee team and Filiz Şahin, for help in collecting the data.

\section{REFERENCES}

1. Așı1k G. Acinetobacter baumannii Virülansının Açıklanmasında Güncel Yaklaşımlar. Mikrobiyol Bul 2011; 45: 371-80.

2. Akın A, Çoruh AE, Alp E, Canpolat DG. Anestezi Yoğun Bakım Ünitesinde Beş Yıl içerisinde Gelişen Nozokomiyal Enfeksiyonlar ve Antibiyotik Direncinin Değerlendirilmesi. Erciyes Tip Dergisi (Erciyes Medical Journal) 2011; 33: 716.

3. Avcı M, Özgenç O, Kıdak LB, Coşkuner A. Evaluation and Monitoring of Device-Associated Infection Rates in Anesthesiology Intensive Care Unit. Turkiye Klinikleri J Med Sci 2009; 29: 917 21.

4. Alpat SN, Aybey AD, Akşit F, Özgüneş İ, Kiremitçi A, Usluer G. Acinetobacter baumannii klinik izolatlarının tigesiklin ve karbapeneme karşı in vitro duyarl11ıkları. Mikrobiyol Bul 2010; 44: 641-5.

5. Balc1 M, Bitirgen M, Kandemir B, Türk Arıbaş E, Erayman İ Nozokomiyal Acinetobacter baumannii suşlarının antibiyotik duyarlılığı. ANKEM Derg 2010; 24: 28-33.

6. Gorbich Y, Karpov I, Kretchikova O. Impact of appropriate antimicrobial therapy on survival in patients with Acinetobacter baumannii-associated infections. JMID 2013; 3: 163-8.

7. Horan TC, Andrus M, Dudeck MA. CDC/NHSN surveillance definition of health care-associated infection and criteria for specific types of infections in the acute care setting. Am J Infect Control 2008; 36: 309-32.

8. Almasaudi SB. Acinetobacter spp. as nosocomial pathogens: Epidemiology and resistance features. Saudi Journal of Biological Sciences 2016; http://dx.doi.org/10.1016/j.sjbs.2016.02.009 (article in press).

9. Alıcı Ö, Ağalar C, Öztürk S, Akgün N. Fatih Sultan Mehmet Eğitim ve Araştırma Hastanesi Yoğun Bakım Ünitesinde İnvasiv Araç İlişkili Hastane Enfeksiyonları; 4 Yillık Deneyim. Boğaziçi Tıp Dergisi 2014; 1: 114-8.

10. Karasu D, Yılmaz C, Durmuş G, Özer D, Çağlayan Ü, Karaduman İ, Asan A. Yoğun Bakım Ünitesinde Uzun Süre Tedavi Edilen Kritik Durumdaki Hastalarda Sağlık Bakımıyla İlişkili İnfeksiyonların Değerlendirilmesi. Klimik Dergisi 2016; 29): 72-7.

11. Mahamat A, Bertrand X, Moreau B, Hommel D, Couppie P, Simonnet C, Kallel H, Demar M, Djossou F, Nacher M. Clinical epidemiology and resistance mechanisms of carbapenem-resistant Acinetobacter baumannii, French Guiana, 20082014. Int J Antimicrob Agents 2016; 48: 51-5.

12. Taşova Y, Yaman A, Saltoğlu N, Yılmaz G, Kara O, Dündar İH. Nozokomiyal Acinetobacter İnfeksiyonlar1. Flora 1999; 4: 170-6.

13. Liu H, Wu YQ, Chen LP, Gao X, Huang HN, Qiu FL, Wu DC. Biofilm-Related Genes: Analyses in Multi-Antibiotic Resistant Acinetobacter Baumannii Isolates From Mainland China. Med Sci Monit 2016 28; 22: 1801-7.

14. Cesur S, Toros GY, Altın N, Koldaş K, Solgun $\mathrm{G}$, Şencan İ. Bir Eğitim ve Araştırma Hastanesinin Yoğun Bakım Ünitelerinde Yatan Hastalardan İzole Edilen Çoklu İlaca Dirençli Acinetobacter baumannii Suşlarının Antibiyotik Duyarlılıkları. Ortadoğu Tıp Dergisi 2016; 8: 59-63. 
15. Sahu MK, Siddharth B, Choudhury A, Vishnubhatla S, Singh SP, Menon R, Kapoor PM, Talwar S, Choudhary S, Airan B. Incidence, microbiological profile of nosocomial infections, and their antibiotic resistance patterns in a high volume Cardiac Surgical Intensive Care Unit. Ann Card Anaesth 2016; 19: 281-7.

16. Sohail M, Rashid A, Aslam B, Waseem M, Shahid M, Akram M, Khurshid M, Rasool MH. Antimicrobial susceptibility of Acinetobacter clinical isolates and emerging antibiogram trends for nosocomial infection management. Rev Soc Bras Med Trop 2016; 49: 300-4.

17. Yurtsever SG, Altıner NN, El S, Çetin FL, Pişmişoğlu E, Uzun S. Hastane infeksiyonu etkeni olarak çeşitli klinik örneklerden izole edilen Acinetobacter baumannii izolatlarının antibiyotik duyarl111klar1. ANKEM Derg 2008; 22: 148-52.

18. Central Asian and Eastern European Surveillance of Antimicrobial Resistance. Annual report 2016. (http://www.euro.who.int/_data/assets/pdf_file/0 009/323568/CAESAR-Annual-report2016.pdf?ua=1).

19. Özdem B, Gürelik FÇ, Çelikbilek N, Balıkçı H, Açıkgöz ZC. Çeşitli Klinik Örneklerden 20072010 Yillarında İzole Edilen Acinetobacter Türlerinin Antibiyotik Direnç Profilleri. Mikrobiyol Bul 2011; 45: 526-34.

20. Coşar M, Tuncer Eİ, Arslan U, Mansur A, Otlu B, Türk Dağı H, Fındık D, Durmaz R. Kan Kültürlerinden Soyutlanan Acinetobacter baumannii Suşlarında PER-1 Tipi Beta Laktamaz Varlığı ve Klonal Yakınlığının Araştırılması. Turkiye Klinikleri J Med Sci 2013; 33: 389-95.

21. Doruk S, Köseoğlu Hİ, Yenişehirli G, Etikan İ, Sağlam DA, Yılmaz A, Kaya S, Günal Ö. Multidrug Resistance Among A. baumannii Isolates from Intensive Care Unit: A Four Years Retrospective Study. Turkiye Klinikleri Arch Lung 2016; 17: 15-20. 